Katarzyna MajchrzaK*

\title{
ŁĄCZENIE PRACY Z OPIEKĄ I WYCHOWANIEM DZIECKA W ŚWIETLE PRZEPISÓW PRAWA PRACY
}

\section{Wstęp}

Zgodnie z przepisami polskiego prawa pracy pracownikom przysługują urlopy związane z szeroko rozumianym rodzicielstwem, których celem jest sprawowanie opieki i wychowanie dzieci. Kodeks pracy przewiduje kilka rodzajów takich urlopów. Po pierwsze pracownica, która urodzi dziecko ma prawo do urlopu macierzyńskiego. Skorzystanie $\mathrm{z}$ tego urlopu jest obowiązkowe. Przy czym po wykorzystaniu po porodzie co najmniej 14 tygodni urlopu macierzyńskiego, pracownica ma prawo zrezygnować z pozostałej części tego urlopu i powrócić do pracy. Jednak ustawodawca $\mathrm{w}$ art. $180 \S 4$ Kodeksu pracy ${ }^{1}$ wprowadził warunki, konieczne do spełnienia przez ojca dziecka, aby pracownica - matka mogła zrezygnować z pozostałej części tego urlopu, a mianowicie: 1) pozostałą część urlopu macierzyńskiego wykorzysta pracownik - ojciec wychowujący dziecko, lub 2) przez okres odpowiadający okresowi, który pozostał do końca urlopu macierzyńskiego osobistą opiekę nad dzieckiem będzie sprawował ubezpieczony - ojciec dziecka, który w celu sprawowania tej opieki przerwał działalność zarobkową. Natomiast pracownik, który przyjął dziecko na wychowanie i wystąpił do sądu opiekuńczego z wnioskiem o wszczęcie postępowania w sprawie przysposobienia dziecka lub też przyjął dzie-

* Dr, Uniwersytet Kardynała Stefana Wyszyńskiego; radca prawny; e-mail: kasia_majchrzak@wp.pl.

${ }^{1}$ Ustawa z dnia 26 czerwca 1974 r. - Kodeks pracy, Dz. U. z 2016 r. poz. 1666 z późn. zm. (dalej: k.p.). 
cko na wychowanie jako rodzina zastępcza może wystąpić do pracodawcy z wnioskiem o urlop na warunkach urlopu macierzyńskiego. Ponadto ustawodawca przewidział także urlop rodzicielski, urlop ojcowski oraz urlop wychowawczy². Skorzystanie z tych urlopów jest dobrowolne i uzależnione od chęci czy też możliwości ich wykorzystania przez rodziców.

Szerokie uprawnienia urlopowe dla pracowników - rodziców z jednej strony umożliwiają prawidłowe wychowanie i rozwój dzieci w rodzinie, ale $\mathrm{z}$ drugiej strony korzystanie $\mathrm{z}$ nich $\mathrm{w}$ pełnym wymiarze powoduje często utratę kontaktu z zakładem pracy (z pracodawcą), a w konsekwencji nawet utratę pracy. Stąd wydaje się zasadnym rozwiązaniem umożliwienie łączenia pracy z opieką i wychowaniem dziecka. W niniejszym artykule uwaga zostanie poświęcona głównie możliwości łączenia pracy z jednoczesnym korzystaniem z urlopu rodzicielskiego i urlopu wychowawczego.

\section{1. Łączenie urlopu macierzyńskiego i ojcowskiego z pracą}

W zakresie możliwości łączenia pracy z urlopem macierzyńskim lub ojcowskim ustawodawca nie wprowadził żadnej regulacji. Można zatem przyjąć, że gdyby ustawodawca chciał wprowadzić taką możliwość, dałby temu wyraz w stosownym przepisie, tak jak to uczynił w przypadku urlopu rodzicielskiego i wychowawczego. Dlatego wydaje się, że w trakcie korzystania z urlopu macierzyńskiego, jak również urlopu ojcowskiego, pracownik nie powinien podejmować żadnej aktywności zawodowej.

Kwestią otwartą pozostaje możliwość podjęcia pracy w czasie urlopu macierzyńskiego i ojcowskiego na podstawie umowy cywilnoprawnej - u tego samego lub innego pracodawcy. Zawarcie takiej umowy, np. umowy zlecenia, nie powoduje automatycznego naruszenia prawa pracy. Jednak z pewnością fakt takiego zatrudnienia, szczególnie w trakcie urlopu macierzyńskiego, może być wnikliwie badany przez inspektora pracy. Kontroli może podlegać zgodność rodzaju umowy (cywilnoprawnej) z warunkami, w jakich jest wykonywana praca. Jeżeli w rzeczywistości

${ }^{2}$ Do 2 stycznia 2016 r., tj. do dnia wejścia w życie ustawy z dnia 24 lipca 2015 r. o zmianie ustawy - Kodeks pracy oraz niektórych innych ustaw (Dz. U. z 2015 r. poz. 1268), pracownicy mogli korzystać jeszcze z dodatkowego urlopu macierzyńskiego oraz dodatkowego urlopu na warunkach urlopu macierzyńskiego. 
odpowiada ona typowemu zatrudnieniu pracowniczemu, pracodawca może się spodziewać zarzutu „przykrycia” stosunku pracy przez umowę prawa cywilnego oraz akceptacji nieprawidłowego wykorzystywania urlopu macierzyńskiego przez pracownika.

Jednocześnie warto także zwrócić uwagę, że wymiar urlopu ojcowskiego jest stosunkowo krótki (do 2 tygodni), dlatego tym bardziej powinien być on wykorzystany jedynie w celu sprawowania opieki i wychowania dziecka. Natomiast urlop macierzyński przysługuje w początkowym okresie życia dziecka, w którym bardziej niż kiedykolwiek później dziecko wymaga sprawowania osobistej opieki rodziców, zwłaszcza matki. Choćby z tych przyczyn i mając na uwadze dobro dziecka, w trakcie korzystania z urlopu macierzyńskiego i ojcowskiego nie powinno się podejmować żadnych aktywności zawodowych.

\section{2. Łączenie urlopu rodzicielskiego z pracą}

Urlop rodzicielski można łączyć z wykonywaniem pracy, zarówno u swojego dotychczasowego pracodawcy, który udzielił urlopu, jak i u nowego (innego) pracodawcy. W pierwszym przypadku pracownik możełączyć korzystanie z urlopu rodzicielskiego z wykonywaniem pracy w wymiarze nie wyższym niż połowa pełnego wymiaru czasu pracy. $W$ takim przypadku urlopu rodzicielskiego udziela się na pozostałą część wymiaru czasu pracy ${ }^{3}$. Ograniczenie możliwości pracy do połowy wymiaru czasu pracy obowiązuje tylko $\mathrm{w}$ przypadku pracy u pracodawcy udzielającego urlopu. Przy czym, od 2 stycznia 2016 r., w myśl przepisu art. $182^{1 \mathrm{ff}} \S 1$ k.p., wymiar urlopu rodzicielskiego wydłużony został proporcjonalnie do wymiaru czasu pracy wykonywanej przez pracownika w trakcie łączenia korzystania z tego urlopu (lub jego części) z praca, maksymalnie do 64 tygodni (w przypadku korzystania z urlopu rodzicielskiego udzielonego na jedno dziecko) lub do 68 tygodni (w przypadku korzystania z urlopu rodzicielskiego udzielonego na dwoje lub więcej dzieci urodzonych przy jednym porodzie) $)^{4}$.

${ }^{3}$ K. Rączka, Uprawnienia pracowników związane z rodzicielstwem, [w:] M. Gersdorf, K. Rączka, M. Raczkowski (red.), Kodeks pracy. Komentarz, Warszawa 2014, s. 1005.

${ }^{4}$ Przykładowo: pracownik korzysta z części urlopu rodzicielskiego z 8 tygodni i łączy go z wykonywaniem pracy w wymiarze połowy pełnego wymiaru czasu pracy. Nato- 
Ograniczenia pracy do połowy wymiaru czasu pracy nie ma w sytuacji, gdy w trakcie urlopu rodzicielskiego pracownik - rodzic podejmuje pracę u nowego (innego) pracodawcy. Ustawodawca nie wprowadził zakazu nawiązywania stosunku pracy $\mathrm{w}$ trakcie korzystania $\mathrm{z}$ urlopu rodzicielskiego. Wydaje się zatem, że mając na uwadze zasadę swobody nawiązania stosunku pracy wyrażoną w art. 11 k.p. koniecznym jest jedynie zgodne oświadczenie woli pracownika i pracodawcy. Strony ustalają warunki pracy i płacy i nie ma żadnych przeszkód prawnych, aby pracownik przebywając na urlopie rodzicielskim nawiązał drugi stosunek pracy u innego pracodawcy niż pracodawca udzielający mu urlopu ${ }^{5}$. Przy czym ważne jest, aby podjęcie tej pracy nie doprowadziło do wyłączenia możliwości sprawowania osobistej opieki nad dzieckiem.

Ponadto ustawodawca nie przewidział także żadnych ograniczeń w podejmowaniu pracy na podstawie umów cywilnoprawnych. Korzystając z urlopu rodzicielskiego możliwe jest jednoczesne podjęcie pracy na podstawie np. umowy zlecenia, umowy o dzieło czy też w ramach prowadzenia działalności gospodarczej zarówno u pracodawcy, który udzielił urlopu rodzicielskiego, jak i u innego podmiotu.

Oprócz tych dwóch głównych sytuacji łączenia urlopu rodzicielskiego $\mathrm{z}$ pracą u pracodawcy udzielającego urlopu oraz innego (nowego) pracodawcy warto także zwrócić uwagę na nieco bardziej skomplikowany przypadek, kiedy pracownik świadczy pracę w ramach kilku umów o pracę (pracuje na kilku etatach). Ustawodawca nie wprowadził żadnych dodatkowych ograniczeń w tym zakresie. Dlatego jeżeli pracownik pracuje na cały etat $u$ pracodawcy A oraz na cały etat $u$ pracodawcy B, łączenie pracy z urlopem rodzicielskim jest możliwe zarówno u jednego, jak i u dwóch pracodawców. Uprawnienia rodzicielskie przysługują oddzielnie na każdy stosunek pracy. Nie ma konieczności (brak wymogu

miast $\mathrm{w}$ pozostałym okresie urlopu rodzicielskiego nie zamierza łączyć go z wykonywaniem pracy. W takim przypadku 8 tygodni urlopu rodzicielskiego mnożymy przez połowę etatu (wymiar czasu pracy, w którym pracownik pracuje) i otrzymujemy wynik równy 4 tygodnie, tj. wymiar urlopu rodzicielskiego, o który nastąpi proporcjonalne wydłużenie urlopu rodzicielskiego.

${ }^{5}$ Odmiennie nieco brak regulacji zakazującej podjęcie dodatkowego zatrudnienia pracowniczego lub niepracowniczego interpretuje A. Sobczyk. Autor stoi na stanowisku, że: „W braku jednoznacznego zakazu nie można go domniemywać. Powyższe stanowi oczywistą niespójność systemu. Ewentualnych konsekwencji można poszukiwać w naruszeniu obowiązku lojalności wobec pracodawcy". A. Sobczyk, Uprawnienia pracowników związane z rodzicielstwem, [w:] A. Sobczyk (red.), Kodeks pracy. Komentarz, Warszawa 2014, s. 685. 
prawnego) korzystania z powyższych uprawnień w takim samym zakresie u pracodawcy A i B. Możliwe jest zatem, aby u pracodawcy A przebywać na urlopie rodzicielskim, natomiast u pracodawcy B powrócić do pracy, nawet w pełnym wymiarze czasu pracy. Są to bowiem dwa odrębne stosunki pracy, zaś urlop rodzicielski jest uprawnieniem fakultatywnym i nie ma przeszkód prawnych, aby w jednym z równoległych stosunków pracy pracownik z niego skorzystał, a w drugim nie.

Aby skorzystać z możliwości łączenia pracy z urlopem rodzicielskim, pracownik, zgodnie $\mathrm{z}$ art. $182^{1 \mathrm{e}} \S 2$ k.p., musi złożyć wniosek $\mathrm{w}$ terminie nie krótszym niż 21 dni przed rozpoczęciem wykonywania pracy ${ }^{6}$. We wniosku należy określić wymiar czasu pracy, w jakim ma być wykonywana praca oraz okres, przez który pracownik zamierza łączyć korzystanie z urlopu z wykonywaniem pracy. Przy czym okresy te nie muszą się pokrywać, to znaczy pracownik może korzystać z urlopu rodzicielskiego w wymiarze dłuższym niż okres łączenia tego urlopu z pracą. Decyzję $\mathrm{w}$ tym zakresie podejmuje pracownik i przedstawia stosowny wniosek. Zasadniczo pracodawca jest związany wnioskiem pracownika. Jednak nie jest to roszczenie bezwzględne. Ustawodawca przewidział wyjątki od tej zasady. Pracodawca może odmówić zrealizowania wniosku pracownika z powodów merytorycznych, jakimi są nieracjonalność wykonywania pracy na zajmowanym stanowisku ze względu na rodzaj bądź organizację pracy. Wydaje się, że wprowadzone przez ustawodawcę ograniczenia są rozwiązaniem uzasadnionym, bowiem nie każda praca może być świadczona w wymiarze nieprzekraczającym połowy dobowego wymiaru czasu pracy. W praktyce mogłoby to spowodować duże utrudnienia organizacyjne dla pracodawcy ${ }^{7}$. Zatem mimo formalnego prawa zagwarantowanego w Kodeksie pracy, w rzeczywistości realna pozycja pracownika $\mathrm{w}$ takim przypadku jest zdecydowanie słabsza niż pozycja pracodawcy. Odmowa pracodawcy musi być uargumentowana, a informacja $\mathrm{w}$ tym zakresie pisemnie przekazana pracownikowi ${ }^{8}$. Jednakże zakwestionowanie przyczyny odmowy i wskazanie, że istnieje możliwość u danego pracodawcy skorzystania z przedmiotowego uprawnienia byłoby bardzo trudne. W sferze oceny tych możliwości mieszczą się bowiem elementy ekonomiczne, personalne, ale także wola pracodawcy. Jednocześnie decyzja odmowna pracodawcy nie byłaby sprzeczna z zasadami współży-

${ }^{6}$ Do 2 stycznia 2016 r. niniejszy termin wynosił 14 dni.

7 M. Latos-Miłkowska, Urlop rodzicielski, „Monitor Prawa Pracy” 2013, nr 8, s. 401.

8 A. Sobczyk, Uprawnienia pracowników zwiazane z rodzicielstwem, s. 684. 
cia społecznego, ponieważ dotyczy sfery organizacyjnej, a nie moralności (pojęcie zasady współżycia społecznego łączy się ze sferą moralności i obyczajowości $)^{9}$. Wydaje się zatem, że dochodzenie tego uprawnienia na drodze sądowej byłoby trudne. W doktrynie wyrażono pogląd, iż: „nie jest jasne, jaki charakter miałaby odmowa. Z jednej strony można by przypuszczać, że wobec pracodawcy mogłoby zostać zgłoszone roszczenie na podstawie art. 471 k.c. o odszkodowanie, a z drugiej strony niezgoda co do wniosku pracownika o zmniejszenie wymiaru czasu pracy ze względu na prawo do urlopu rodzicielskiego mogłaby zostać uznana za wykroczenie na podstawie art. 281 pkt 5 k.p." ${ }^{10}$ Inaczej w przypadku, gdyby u pracodawcy było kilku pracowników łączących pracę z urlopem rodzicielskim; wówczas odmowa mogłaby być naruszeniem zasady równego traktowania w zatrudnieniu (art. $18^{3 a} \S 1$ k.p.).

Warto także podkreślić, że w przypadku łączenia urlopu rodzicielskiego z wykonywaniem pracy u pracodawcy udzielającego urlopu, a zatem w wymiarze nie wyższym niż połowa pełnego wymiaru czasu pracy nie oznacza konieczności wykonywania jej w sztywnym rozkładzie czasu pracy. Jeżeli pracownik będzie wykonywał pracę w wymiarze 1/2 etatu, nie oznacza to w praktyce, że będzie świadczył pracę po 4 godziny dziennie. Możliwy jest inny rozkład czasu pracy, przewidujący mniejszą liczbę dni pracy w wyższym wymiarze. Ważne, aby pracownik wykonywał pracę nie przekraczając połowy pełnego wymiaru czasu pracy. Możliwe jest także, aby w okresie łączenia urlopów związanych z rodzicielstwem z pracą skorzystać z ruchomego czasu pracy. Pracownik składając wniosek w sprawie łączenia urlopu z pracą może także zawnioskować o stosowanie do niego ruchomego czasu pracy. Jednak, o ile wniosek o łączenie urlopu z pracą pracodawca zobowiązany jest uwzględnić (mając na uwadze powyższe rozważania), o tyle nie ma już obowiązku wyrażenia zgody na ruchomy czas pracy. Dodatkowo pracodawca odmawiając nie ma konieczności przedstawiania pisemnej argumentacji swojej decyzji11.

${ }^{9}$ J. Wiśniewski, Kilka refleksji dotyczacych uprawnień pracowników związanych z rodzicielstwem w świetle znowelizowanych regulacji prawnych, „Studia z Zakresu Prawa, Administracji i Zarządzania UKW" 2014, t. 2, s. 123.

${ }^{10}$ B. Godlewska-Bujok, Nowe regulacje uprawnień zwiazanych z rodzicielstwem, „Praca i Zabezpieczenie Społeczne" 2013, nr 7, s. 26.

${ }_{11}$ M. Frączek, A. Konarska, Pracownicze urlopy zwiazane z rodzicielstwem - nowe uprawnienia i obowiazki stron stosunku pracy, Warszawa 2013, s. 133-134; R. Lisicki, Urlopy zwiazane z petnieniem funkcji rodzicielskich, „Praca i Zabezpieczenie Społeczne” 2014, nr 11, s. 40. 
Przy łączeniu urlopu rodzicielskiego z wykonywaniem pracy u pracodawcy udzielającego tego urlopu pracownik będzie otrzymywał stosowne wynagrodzenie za czas przepracowany (np. za 1/2 etatu) oraz proporcjonalnie obniżony zasiłek macierzyński za czas urlopu rodzicielskiego.

Odrębnym zagadnieniem jest natomiast, czy łączenie pracy z urlopem rodzicielskim jest właściwe, czy jest dobrym rozwiązaniem. Czy pracownik może pogodzić opiekę i wychowanie dziecka z wykonywaniem pracy, zwłaszcza w pełnym wymiarze czasu pracy? Udzielenie odpowiedzi na te pytania wymagałoby głębszej analizy. Nie jest to z pewnością jednoznaczne i nie ma prostego i słusznego rozwiązania. $Z$ jednej strony pracownikowi, który ma stały kontakt z pracą (poza urlopem macierzyńskim) łatwiej wrócić na dotychczasowe stanowisko pracy. Jednak z drugiej strony asumptem do korzystania z urlopu rodzicielskiego jest przede wszystkim sprawowanie opieki nad dzieckiem. Wydaje się, że dobrym sposobem na łączenie urlopu rodzicielskiego z pracą będzie świadczenie pracy na podstawie umów cywilnoprawnych. Umowy te przewidują bowiem większą swobodę w zakresie czasu, miejsca i sposobu wykonywania pracy.

\section{3. Łączenie urlopu wychowawczego z pracą}

Zgodnie z art. $186^{2}$ k.p. pracownik ma prawo w trakcie korzystania $\mathrm{z}$ urlopu wychowawczego do podjęcia pracy u dotychczasowego albo innego (nowego) pracodawcy. Pracownik może także podjąć inną działalność, naukę lub szkolenie, przy czym żadna z tych aktywności nie może uniemożliwiać sprawowania osobistej opieki nad dzieckiem. Dlatego należy w pierwszej kolejności ustalić, czy dana praca lub inna działalność nie przeszkadza w sprawowaniu osobistej opieki nad dzieckiem. Ocena każdorazowo uzależniona jest od charakteru i wymiaru podjętej aktywności zawodowej. W praktyce przyjmuje się, że praca $\mathrm{w}$ granicach połowy etatu nie koliduje $\mathrm{z}$ obowiązkami rodzicielskimi. W jednym z wyroków Naczelny Sąd Administracyjny wskazał: „Podjęcie zatrudnienia w okresie korzystania przez pracownika z urlopu wychowawczego jest dopuszczalne wyjątkowo wtedy, gdy nie doprowadzi do wyłączenia możliwości sprawowania osobistej opieki nad dzieckiem. Ocena co do możliwości sprawowania przez pracownika osobistej opieki nad dzie- 
ckiem musi odnosić się do czasu podjętej pracy, a nie do całego okresu urlopu wychowawczego"12.

Analogicznie jak przy urlopie rodzicielskim, również w sytuacji łączenia pracy z urlopem wychowawczym dopuszczalne jest zawarcie umowy cywilnoprawnej.

Możliwe jest także zawarcie z pracownikiem przebywającym na urlopie wychowawczym dodatkowej (nowej) umowy o pracę na część etatu lub też zmniejszenie wymiaru dotychczasowej umowy.

Ustawodawca przewidział także sytuację, kiedy pracownik, łącząc urlop wychowawczy z praca, trwale zaprzestanie sprawowania osobistej opieki nad dzieckiem. Wówczas pracodawca jest uprawniony, aby wezwać pracownika do stawienia się do pracy w terminie przez siebie wskazanym, nie później jednak niż w ciągu 30 dni od dnia, kiedy taką informację powziął, a jednocześnie nie wcześniej niż po upływie 3 dni od dnia wezwania pracownika. Termin stawienia się do pracy ustala pracodawca. Przyjmuje się, że wezwanie jest rodzajem polecenia służbowego. Dlatego niewykonanie tego polecenia i niestawienie się do pracy we wskazanym przez pracodawcę terminie będzie stanowiło naruszenie obowiązków pracowniczych $^{13}$.

Ustawodawca mówi wyraźnie o trwałym zaprzestaniu sprawowania opieki. Zatem krótsze (kilkugodzinne) czy nawet dłuższe (kilkudniowe) okresy, kiedy pracownik nie będzie osobiście sprawował opieki, ale będzie ona zapewniona, nie mogą stanowić podstawy do uznania, że pracownik zaprzestał całkowicie sprawowania opieki nad dzieckiem. Może się zdarzyć, że pracownik z powodu choroby będzie przebywał w szpitalu albo wyjedzie na kilka dni urlopu czy podróży służbowej ${ }^{14}$. W doktrynie słusznie uznaje się, że nawet wyjazd na 2-tygodniowy kurs szkoleniowy zwłaszcza związany z wykonywaną pracą nie powinien stanowić podstawy do uznania, że pracownik trwale zaprzestał sprawowania osobistej opieki nad dzieckiem. W konsekwencji wezwanie pracownika do stawienia się do pracy byłoby $\mathrm{w}$ takiej sytuacji bezzasadne ${ }^{15}$.

12 Wyrok Naczelnego Sądu Administracyjnego z 25 marca 2011 r., I OSK 2066/10, LEX nr 1079748.

13 A. Sobczyk, Uprawnienia pracowników zwiazane z rodzicielstwem, s. 703.

${ }_{14}$ M. Włodarczyk, Uprawnienia pracowników zwiąane z rodzicielstwem, [w:] K.W. Baran (red.), Kodeks pracy. Komentarz, Warszawa 2014, s. 1089.

${ }^{15}$ F. Małysz, Urlop wychowawczy - po zmianach, „Służba Pracownicza” 2014, nr 5, s. 3. 


\section{Zakończenie}

Urlopy związane $\mathrm{z}$ rodzicielstwem, $\mathrm{w}$ tym urlop rodzicielski i wychowawczy spotykają się z coraz większym poparciem społeczeństwa, zwłaszcza kobiet. Nadal to głównie kobiety korzystają z szeroko rozumianych uprawnień rodzicielskich. Niestety, efektem ubocznym tego rozwiązania jest nadal gorsza pozycja kobiet na rynku pracy. Pracodawcy niechętnie zatrudniają pracownice - matki. Nieobecność kobiety w pracy, z uwagi na posiadanie potomstwa, naraża ją na utratę zatrudnienia. Dlatego możliwość łączenia pracy z opieką i wychowaniem dziecka jest dobrym rozwiązaniem, aby nie tracić zupełnie kontaktu z zakładem pracy (z pracodawcą).

Reasumując, wydaje się, że możliwość łączenia pracy z urlopem rodzicielskim i wychowawczym jest rozwiązaniem słusznym i korzystnym dla pracowników. Należy jednak zawsze pamiętać, że podjęcie pracy w trakcie trwania ww. urlopów nie zmienia statusu pracownika, zatem będzie on nadal przebywał na urlopie rodzicielskim bądź wychowawczym. Dlatego trzeba koniecznie pamiętać, co jest istotą niniejszych urlopów. Pracownik korzysta z urlopu rodzicielskiego bądź wychowawczego w celu sprawowania opieki i wychowania dziecka. Stąd łączenie pracy z urlopami nie powinno kolidować z obowiązkami rodzicielskimi, które winny być na pierwszym miejscu. Ponadto wydaje się wskazane, aby promować i popierać pracodawców, którzy umożliwiają swoim pracownikom łączenie pracy z jednoczesnym korzystaniem z urlopu rodzicielskiego lub wychowawczego. Warto także, aby pracownicy świadomi swoich praw chętniej korzystali z omawianych wyżej rozwiązań prawnie dopuszczalnych.

Słowa kluczowe: prawo pracy, uprawnienia rodzicielskie, urlopy rodzicielskie

\section{Bibliografia}

Frączek M., Konarska A., Pracownicze urlopy zwiazane z rodzicielstwem - nowe uprawnienia i obowiazki stron stosunku pracy, Warszawa 2013.

Godlewska-Bujok B., Nowe regulacje uprawnień zwiazanych z rodzicielstwem, „Praca i Zabezpieczenie Społeczne” 2013, nr 7.

Latos-Miłkowska M., Urlop rodzicielski, „Monitor Prawa Pracy” 2013, nr 8. 
Lisicki R., Urlopy zwiazane z petnieniem funkcji rodzicielskich, „Praca i Zabezpieczenie Społeczne" 2014, nr 11.

Małysz F., Urlop wychowawczy - po zmianach, „Służba Pracownicza” 2014, nr 5. Rączka K., Uprawnienia pracowników zwiazane z rodzicielstwem, [w:] M. Gersdorf, K. Rączka, M. Raczkowski (red.), Kodeks pracy. Komentarz, Warszawa 2014.

Sobczyk A., Uprawnienia pracowników zwiazane z rodzicielstwem, [w:] A. Sobczyk (red.), Kodeks pracy. Komentarz, Warszawa 2014.

Wiśniewski J., Kilka refleksji dotyczacych uprawnień pracowników zwiazanych z rodzicielstwem w świetle znowelizowanych regulacji prawnych, „Studia z Zakresu Prawa, Administracji i Zarządzania UKW" 2014, t. 2.

Włodarczyk M., Uprawnienia pracowników zwiazane z rodzicielstwem, [w:] K.W. Baran (red.), Kodeks pracy. Komentarz, Warszawa 2014.

\section{COMBINING WORK WITH CHILD CARE IN THE LIGHT OF LABOUR LAWS}

\section{S u m m a r y}

The article presents the possibility of combination of leaves connected with parenthood with performance of work. The primary objective of leaves connected with parenthood is providing care and upbringing to children. However, bearing in mind such elements as the Polish employment market and financial position of the parents, the legislator has provided with parent employees with possibility to combine child care with work. An employee on parental leave can undertake work at the enterprise of the employer who awarded the said leave as well as for another employer or undertake a different activity, also education or training. It is important that the undertaken work or other activity cannot exclude the possibility of obtaining the objective of the provided leave, i.e. taking care over the child.

Key words: labour law, parental rights, parental leaves

\section{СОВМЕЩЕНИЕ РАБОТЫ С ПРИСМОТРОМ И ВОСПИТАНИЕМ РЕБЕНКА НА ОСНОВАНИИ ПОЛОЖЕНИЙ ЗАКОНА РАБОТЫ}

$$
\text { P е } 3 \text { го м }
$$

Статья представляет возможности совмещения отпусков, связанных с родительством с выполнением работы. Принципиальной целью отпусков, связанных с родительством, есть обеспечение присмотра и воспитание детей. Однако, имея в виду, именно польский рынок труда, а также финансовую ситуацию родителей законодатель предусмотрел для 
работников-родителей возможность совмещать обеспечения присмотра с работой. Работник, состоящий в родительском отпуске и воспитательном отпуске, имеет право начать работу у того же работодателя, который дал ему такой отпуск, как и у другого работодателя другой деятельность, а также науку или практику. Важное, чтобы начатая работа или другая деятельность не исключала возможность реализации цели данного отпуска, то есть осуществление опеки за ребенком.

Кдючевые слова: трудовое право, родительские подномочия, родительские отпуска 